\title{
PERAN PARALEGAL DALAM PERLINDUNGAN SERTA PEMENUHAN HAK HUKUM MASYARAKAT
}

\author{
Neo Adhi Kurniawan \\ neo.adhi.fis@um.ac.id \\ Jurusan Hukum dan Kewarganegaraan, Fakultas IImu Sosial, Universitas Negeri Malang \\ Diterima 18 April 2020, Diterbitkan 30 April 2020
}

\begin{abstract}
Abstrak
Selain menyiapkan masyarakat yang sadar hukum, paralegal juga memberikan legalitas kepada masyarakat yang sedang berhadapan dalam hukum, maupun sedang memberikan advis atau pelayanan di bidang hukum kepada masyarakat luas sapai dengan tahap penyidikan di kepolisian, karena warga desa yang dilatih akan mendapatkan sertifikasi yang legal dan diakui oleh instansi pemerintah.Pengabdian kepada masyarakat ini mengunakan metode atau pendekatan Edukatif yaitu pendekatan yang dalam program maupun pelaksanaan pengabdian mengandung unsur pendidikan yang dapat mendinamisasikan masyarakat menuju kemajuan yang dicita-citakan, Partisipatif yaitu pendekatan yang berorientasi kepada upaya peningkatan peran serta masyarakat secara langsung dalam berbagai proses dan pelaksanaan, Normatif yaitu pendekatan yang didasarkan kepada norma, nilai, hukum dan peraturan perundangan yang berlaku.Pengabdian kepada masyarakat ini telah selesai dilaksanakan dan menghsilkan beberapa hasil yang telah direncanakan, seperti terbantuknya komunitas paralegal desa yang bisa saling bertukat pikiran terkait masalah hukum serta solusi apa yang dapat diberikan, semakin bertambahnya pengetahuan dalam bidang hukum dan kedewasaan masyarakat dalam melihat permasalahan hukum yang ada dan timbul dimasyarakat
\end{abstract}

Kata Kunci: Peran Paralegal, Perlindungan Hukum, Hak Hukum Mayarakat

\section{PENDAHULUAN}

Undang-Undang Nomor 16 Tahun 2011 tentang Bantuan Hukum adalah untuk mewujudkan serta mempermudah dalam mendapatkan jaminan dari keadilan bagi semua lapisan masyarakat, terutama masyarakat yang tergolong miskin atau tidak mampu supaya bisa memperoleh hak hukum masyarakat yang seharusnya didapkan seperti bantuan hukum yang tidak bisa di akses dengan baik karena adanya keterbatasan, baik pengetahuan maupun keterbatasan kemampuan ekonomi dengan menyewa pengacara atau advokat.

Bantuan hukum adalah merupakan jasa hukum yang diberikan oleh pemberi bantuan hukum dengan gratis atau tidak dipungut biaya dari pemberi bantuan hukum yang akan diterima oleh orang yang membutuhkan bantuan yaitu kepada masyarakat miskin. LBH atau lembaga bantuan hukum serta ormas yang mentediakan layanan pemberian bantuan hukum secara gratis, LBH atau lembaga bantuan hukum serta ormas dalam peraturan perundang-undangan diberikan hak hukum untuk mengangkat atau memiliki anggota salah satunya adalah Paralegal, dengan adanya paralegal dari segi hukum Paralegal memiliki peranan serta eksistensi yang di akui oleh undang-undang dalam pemberian bantuan hukum kepada penerima bantuan hukum yaitu masyarakat kurang mampu atau kelompok masyarakat kurang mampu yang berhadapan dengan problematika hukum.

Terdapat kepastian hukum terhadap adanya hak-hak serta bantuan hukum kepada yang membutuhkan seperti yang diamanatkan oleh konstitusi terdapat dalam Pasal $28 \mathrm{~d}$ ayat (1) dan Pasal 28 h ayat (2) Undang-Undang Dasar Negara Republik Indonesia Tahun 1945 yang berbunyi Negara terutama pemerintah sebagai penyelenggaran negara memiliki tanggung jawab dalam pemenuhan hak atas bantuan hukum sebagai hak konstitusional warga negara. Berdasarkan pertimbangan inilah secara yuridis urgennya eksistensi Undang-Undang Bantuan Hukum sehingga diundangkan menjadi sebuah undang-undang bantuan hukum yang tersendiri. 
Paralegal memiliki peranan yang sangat vital atau penting dalam hal pemberian memberikan layanan kepada masyarakat yang membutuhkan bantuan, kehadiran paralegal serta keberadaanya sangat dibutuhkan, dimana masih sangat banyaknya masyarakat atau kelompok masyarakat kurang mampu atau miskin marjinal dan buta hukum di Indonesia yang sulit mendapatkan keadilan yang sangat dibutuhkan oleh mereka, jumlah masyarakat miskin atau kurang mampu sangatlah tinggi serta padat dan merata hampir berada di berbagai wilayah Indonesia yang besar, tetapi tidak sebanding dengan adanya pengacara atau advokat yang ada di wilayah Indonesia.

Selama ini keberadaan dari Paralegal telah memberikan sumbangsih nyata dan pasti di masyarakat, komunitas, atau kelompok masyarakat miskin dengan memberikan pelayananpelayanan bantuan hukum kepada yang membutuhkan. Kebaradaan dari Paralegal dirasakan bisa menjalankan pekerjaan-pekerjaan pemahaman terhadap hukum serta pemenuhan perlindungan di masyarakat luas serta dapat mendorong pertumbuhan serta perberkembangnya dari kesadarankesadaran masyarakat luas serta diharapkan bisa dan mampu mendorong proses demokrasisasi dalam masyarakat.

Diakunya paralegal seperti yang tercantum dalam berbagai peraturan perundang-undangan akan semakin mengokohkan peranan dan kedudukan dari adanya Paralegal dalam melaksanakan tugas, wewenang, tanggungjawab dalam memberikan pemenuhan hukum pada masyarakat pada umumnya, selama ini kedudukan adanya atau kehadiran paralegal mendapatkan sedikit tempat dalam dunia hukum di Indonesia, tidak banyak peraturan yang membehas tentang adanya paralegal dalam peranan yang begitu urgen di bisang hukum Indonesia.

Jika kita lihat lebih jauh lagi tentang adanya palagal, seperti terlihat dalam sejarah serta perkembangan adanya paralegal, paralegal merupakan orang yang tidak memiliki latar belakang pendidikan hukum atau kesarjanaan dibidang hukum, tetapi paralegal adalah orang yang memiliki pengetahuan dna pemahaman yang baik dalam bidang hukum serta sanggup untuk memberikan advis atau advokasi dibidang hukum. Keberadaan dari Paralegal awal mulanya dikenalkan di negara USA pada sekitar tahun 1968 dimana dinegara tersebut memberikan istilah atau pengertian sebagai Legal Asistant dimana dalam pengertian tersebut paralegal memiliki pekerjaan untuk membantu membantu seorang pengacara atau advokat serta notaris dalam memberikan masukan serta tanggapan terhadap sebuah permasalahan hukum kepada masyarakat yang membutuhkan saran sert memiliki kewajiban memberikan laporan kepada kepada legal atau advokat, pengacara atau notaris yang bersangkutan. Dalam menjadi Legal Asistant harus memiliki kemampuan pendidikan atau kecakapan khusus dibidang hukum tetapi Legal Asistant dalam di Indonesia disebut sebagai paralegal harus menjalani pendidikan khusus tetapi tidak bisa beracara atau bersidang di pengadilan, karena hanya bertugas untuk membantu saja.

Kebaradaan Paralegal ada jika sudah melakuikan beberapa kali pelatihan yang dilaksanakan secara khusus dan berjanjang untuk meningkatkan kemampuan secara individu para paralegal serta paralegal diharapkan bisa berjuang dalam memberikan bantuan hukum serta hakhak dari masyaraka yang kuran mampu atau kelompok masyarak miskin dari segi memberikan layanan serta bantuan legal, saat ini kata paralegal sudah ditemukan dalam beberapa peraturan seperti Undang-undang bantuan hukum, PERMENKUMHAM tentang PARALEGAL, walaupun baru belakangan in istilah paralegal muncul parelagal telah sejak dulu mayarakat mengenalnya serta berkembang dalam masyarakat. Kebaradaan dari paralegal di inisasi atau di munculkan serta di dorong keberadaanya oleh kelompok-kelompok organisasi diluar pemerintahan (nongovernment organization), muncul untuk mencoba memberikan layanan berupa pendidikan, pemahaman serta bentuk-bentuk lain seperti pelatihan dalam bidang hukum bagi pencari keadilan khususbya masyarakat miskin, diharapkan masyarakat tersebut memperoleh kemahiran serta kemampuan dalam menuntut hak yang seharusnya didapatkan, sehingga bisa memberikan bantuan serta layanan hukum dalam masyarakat.

Paralegal bukanlah merupakan sebuah pekerjaan atau profesi dan yang bisa meghasilkan uang didalamnya, paralegal adalah murni pengabdian dalam memberikan bantun dalam bidang hukum bagi masyarakat miskin yang membutuhkan bantuan dalam mendapatkan hak-hak yang 
dirampas oleh orang lain maupun dirampas oleh negara.

Paralegal diharuskan mempunyai kemampuan dan integritas diri yang kuat dengan cara diberikan pelatihan atau kemmapuan khusus di bidang hukum dan kader-orang atau kelompk yang sudah berstatus sebagai Paralegal harus memiliki pengetahuan yang terus diasah dan kekinian dalam segi pengetahuan hukum terbaru, dari yang paling sederhana yaitu pengetahuan dasar-dasar hukum, etika paralegal.

sangatlah penting keberadaan lembaga-lembaga yang bertugas memberikan bantuan hukum segera menyiapkan atau mempersiapkan lembaga pendidikan yang di khususkan bagi keberadaan Paralegal sendiri sebagai tempat melahirkan masyarakat-masyarakat serta komunitas dan kader Paralegal yang mumpuni dan berintegritas tinggi. Juga perlu ditegaskan tempat, ruanglingkup dan batasan serta peran tugas dari adanya paralegal supaya tidak bisa disalah artikan atau dianggap sebagai sebuah pekerjaan atau profesi yang bisa menghasilkan uang.

Masyarakat yang tidak memiliki kartu anggota atau sertifikat pelatihan yang di keluarkan (LBH) Lembaga Bantuan Hukum, masyarakat tersebut tidak bisa memberikan advis atau pelayanan kepada yang membutuhkan seperti yang disebutkan didalam UU No. 16 Tahun 2011 tentang Bantuan Hukum, maka dari itu masyaraka disiapkan dalam pelatihan untuk siap dalam memberikan bantuan hukum, Selain menyiapkan masyarakat yang sadar hukum, paralegal juga memberikan legalitas kepada masyarakat yang sedang berhadapan dalam hukum, maupun sedang memberikan advis atau pelayanan di bidang hukum kepada masyarakat luas sapai dengan tahap penyidikan di kepolisian, karena warga desa yang dilatih akan mendapatkan sertifikasi yang legal dan diakui oleh instansi pemerintah, masyarakat yang memiliki sertifikat

Adanya perlakuan yang semua sama didepan hukum memilikikaitan yang sangat kuat dengan adanya hak-hak masyarakat dalam memperoleh bantuan, terutama bantuan hukum bagi masyarakat tidak mampu sebagai salah satu perwujutan pemuhan jaminan terhadap rasakeadilan setiap orang. menurut Winarta (2011:101) memberikan pernyataan bahwa yang di sebut sebagai bantuan hukum atau BANKUM selain adalah MAH juga adalah merupakan gerakan atau perbuatan yang bersifat konstitusi. Pelaksanaan dalam memberikan bantuan hukum atau BANKUM pada masyarakat miskin atau kurang mampu adalah upaya dalampemenuhan serta sebagai sebuah perwujudan dari negara hukum yang berkeadilan serta pengakuan dan melindungi, menjamin HAM dari setiap warga negara akan kebutuhan keadilan (access to justice) dan kesamaan kedudukan di hadapan hukum (equality before the law).

Pelatihan dan sertifikasi paralegal juga menjadi sebuah sarana untuk mensosialisasikan UU No. 16 Tahun 2011 tentang bantuan hukum dimana dalam undang-Undang Bnatuan Hukum ini diberikan hak yang besar bagi warga masyarakat yang ingin berpartisipasi dan terjun memberikan bantuan atau pelayanan dalam bidang hukum dengan menjadi paralegal. Permasalahan yang ada dalam masyarakat tentang kasus-kasus hukum yang selama ini dihadapi oleh masyarakat, seperti kasus sengketa tanah, rumahtangga, hutang piutang dan permasalahan lain yang muncul dalam masyarakat, ketidak tahuan dan awam terhadap hukum dari masyarakat harus diminimalisir karena sudah saatnya masyarakat sadar hukum dan masyarakat berdaya dari segihukum, pengetahuan yang diharaapkan bisa dimiliki dari pelatihan ini dan legalitas yang mereka miliki menjadikan mereka lebih percaya diri dalam menghadapi permasalahan hukum yang akan mereka hadapi nanti

\section{METODE}

Langkah operasional kegiatan yang dilakukan adalah dengan melakukan langkah-langkah yang akan dilaksanakan demi tercapainya tujuan dari kegiatan adalah sebagai berikut, kegiatan awal akan dilaksanakan observasi daerah yang akan dilaksanakan pengabdian kepada masyarakat terlait permasalahan hukum apa yang sering timbul dalam masyarakat, setelah ditemukan garis besar permasalahan maka akan dilaksanakan pemetaan focus peserta yang akan diundang dalam pelatihan ini seperti tokoh masyarakat, perangkat desa, RT/RW, karang taruna dan peserta lainnya berdasarkan data observasi awal yang telah di dapatkan, studi eksplorasi topic dan tema pelatihan setelah menentukan peserta maka akan dibicarakan fakus kajian apa yang akan diambil, modul pelatihan akan disusun berdasarkan topic yang telah ditentukan oleh tim pengabdian kepada 
masyarakat, setelah semua persiapan telah siap maka akan masuk dalam tahap pelaksanaan pelatihan sesual dengan apa yang telah di sekemakan oleh tim tentang peserta dan materi serta target yang ingin didapatkan, pencetakan sertifikat dan kartu akan dilaksanakan dikemudian, evaluasi akan dilaksanakan setelah pelatihan selesai.

Peran paralegal saat ini mempunyai posisi yang sangat strategis dalam dalam perlindungan serta pemenuhan hak-hak hukum masyarakat khususnya masyarakat miskin atau kurang mampu yang ada dilingkungan sekitar paralegal, keberadaan paralegal bertujuan untuk, (1) Mengedukasi masalah hukum masyarakat, (2) Memberikan pendidikan hukum dibidang advis/pelayanan hukum bagi masyarakat, (3) Meminimalisir konflik hukum yang terjadi, (4) Membentuk komunitas-komunitas paralegal yang sadar hukum, (5) Membentuk kopetensi paralegal yang mengerti dan paham tentang prosedur dalam pendampingan masyarakat, (6) Menjadikan masyaraak mandiri dalam bidang hukum, (7) Membantu program pemerintah dalam hal sosialisasi bantuan hukum pada masyarakat, (8) Meningkatkan kemandirian masyarakat dalam bidang hukum, (9) Menjadikan masyarakat lebih peka terhadap permasalahan hukum.

\section{HASIL DAN PEMBAHASAN}

Beberapa istilah yang muncul dan membahas tentang bantuan hukum atau BANKUM dari segi struktural yang salah satunya dikemukakan oleh Sunggono dan Harianto (2001) memberikan definisi bantuan hukum atau BANKUM struktural adalah merupakan sebuah kegiatan yang didalamnya memiliki tujuan untuk menciptakan sebuah keadaan dalam terciptanya hukum yang bisa mengubah struktur yang kurang baik atau menyimpang menuju arah struktur yang tidak menyipang yang lebih dirasakan memberikan rasa adil, bantuan hukum atau BANKUM seharusnya tidak semata-mata hanya memberi pelayanan hukum hanya pada kasus-kasus yang telah ada saja, pemberian bantuan hukum atau BANKUM harus lebih mampu atau bisa untuk memberikan pemahaman terhadap perkara yang ada terklait bagaimana solusi atau jalan terbaik untuki menyelesaikan masalah

Padangan dari Wiratraman (2016) bahwa keberadaan dari paralegal muncul dalam upaya dari lembaga-lembaga bantuan hukum, mendorong terciptanya perlindungan dan melaksanakan upaya hukumyang penting dalam memberikan fasilitas terbentuknya organisasi yang ber orientasi pada rakyat, melakukan pemahaman dan pendidikan, melakukan peningkatan dan penguatan kesadaran, melakukan analisa kebutuhan dalam masyarakat terhadap hukum, advokasi masyarakat.

Ditemukan beberapa hasil temuan diantaranya adalah adanya (1) adanya kebutuhan yang besar terhadap Paralegal, (2) banyak ketidak tahuan masyarakat terhadap hukum, (3) ketidak tahuan masyarakat harus bagaiman dalam menyelesaikan persoalan hukum yang dihadapi, (4) ketakutan masyarakat terhadap permasalahan hukum yang sedang di hadapi, temuan yang didapatkan ditafsirkan bahwa kebutuhan dari adanya paralegal memiliki urgenitas yang cukup tinggi dimana kehadiran paralagel diharapkan bisa untuk: (1) Memberikan solusi pasti pada rmasalahan masyarakat desa dibidang hukum dengan pendekatan yang lebih manusiawi dan dapat diterima oleh semua pihak; (2) Menerapkan hasil penelitian yang sesuai dengan urgensi apa yang dibutuhkan masyarakat; (3) Membeberikan pemahaman kepada masyarakat bahwa untuk mendapatkan bantuan serta pelayanan hukum itu mudah; (4) Memberikan pandangan bahwa hukum bisa diakses oleh siapa saja tanpa terkecuali; (5) Memberikan penguatan potensi masyarakat desa dibidang hukum; (6) Membentuk jaringan desa mitra sebagai salah satu model pemberdayaaan masyarakat

Black's Law Dictionary istilah paralegal mengacu kepada definisi "a person with legal skills, but who is not an attorney, and who works under the supervision of a lawyer or no is otherwise authorized by law to use those legal skills". Paralegal hamper sama dengan pekerjaan seorang yang bekerja di kantor-kantor pengacara, notaris. Di dalam konsep beberapa negar di Eropa dan Amerika, dapat ditemukan bahwa definisi siatas sejalam dengan praktik system bantuan hukum terkait paralegal di kedua Negara tersebut (Abdul Azis Sigalingging, et-al, 2015). 


\section{Pelaksanaan Pengabdian Kepada Masyarakat}

Tahap awal yang diakukan oleh tim pengabdian masyarakat di desa pagedangan kecamatan Turen Kabupaten Malang adalah dengan melakukan Observasi Desa sebagai tahap awal Melakukan observasi awal tentang permasalahan hukum yang banyak terjadi di Desa Pagedangan kcamatan turen, kultur dan kegiatan masyarakat desa, warga-warga desa yang berpotensi untuk direkrut menadi paralegal dikemudian hari, melakukan audiensi dengan pihak desa tentang langkahlangkah dan kebutuhan pelatihan yang akan.

Melakukan pemantapan orang yang akan mengikuti pelatihan, Berdasarkan obsevasi desa dan peserta pelatihan, maka akan ditetapkan fokus topik pelatihan yang mereka butuhkan untuk menyelesaikan permasalahan hukum yang rawan terjadi didesa maupun lingkup kecamatan, Akan dilakukan penyusunan modul pelatihan dan alternatif penyelesaian masalah atau sengketa yang dibutuhkan oleh masyarakat desa, Pelaksanaan kegiatan sesuai dengan agenda kegiatan yang direncanakan oleh panitia, kegiatan akan direncanakan selama 2 malam, kegiatan akan dilaksanakan pada malam hari mengingat pada siang hari sedang beraktifitas dan rutinitas masingmasing.

Tabel 1. Topik Kegiatan dan Narasumber

\begin{tabular}{llll}
\hline \multicolumn{1}{c}{ Topik } & \multicolumn{1}{c}{ Narasumber } & \multicolumn{1}{c}{ Instansi } \\
\hline Hukum dan Masyarakat & $\begin{array}{l}\text { Drs. H. Suparman AW, SH., } \\
\text { M.Hum }\end{array}$ & Universitas Negeri Malang \\
Hak Asasi Manusia & Dr. Hj. Yuniastuti, SH., M.Pd. & Universitas Negeri Malang \\
Paralegal & $\begin{array}{l}\text { Neo Adhi Kurniawan, S.Pd., SH., Universitas Negeri Malang } \\
\text { MH. }\end{array}$ & Dr. Sutoyo, SH., M.Hum & Universitas Negeri Malang \\
Keterampilan atau & &
\end{tabular}

Masyarakat

Harapan dari tim pengabdian kepada masyarakat adalah bertujuan agar rasakeadilan akan dirasakan lebih terasa dalam masyarakat, dimana paralegal akan mengusahana jalur non litigasi atau jalur diluar pengadilan, maka akan ada solusi dalam mengelesaikan permasalahan yang terjadi, solusi yang dianggap baik oleh pihak-pihak yang bersengketa akan merasa lebih terwakili, karena salah satu tugas paralegal adalah memberikan pendampingan dan saran kepada para pihak yang bermasalah.

Masyarakat desa yang sudah memiliki kemampuan untuk mengadvokasi diharapkan bisa memberikan solusi dan mempermudah penyelesaian permasalahan yang muncul dalam masyarakan dengan cara yang cepat, efektif, efisian serta penuh rasa kekeluargaan demi terciptanya rasa keadilan bagi semuanya, paralegal disini memberikan pendidikan hukum bagi masyarakat umum yang tidak berprofesi sebagai pengacara maupun sarjana hukum, semua orang boleh menjadi paralegal demi tercitnya perlindungan hukum yang merata dan penuh rasa keadilan.

Pelaksanaan pengabdian kepada masyarakat ini juga bertujuan dimana bantuan hukum dapat menjamin dan mewujudkan persamaan di hadapan hukum dengan membela hak-hak orang miskin, sejalan dengan pendapat dari berhasilnya pelaksanaan bantuan hukum atau BANKUM sebagai gerakan konstitusi akan diharapkan mampu untuk mengatasi potensi gejolak-gejolak dan keresahan-keresahan secara sosial, juga akan mendorong pencapaian Negara hukum yang dicitacitakan (Frans Hendra Winarta, 2011).

Pasal 2 PERMENKUMHAM No. 1 Tahun 2018 tentang adanya paralegal didalam proses Pemberian Bantuan Hukum, Paralegal yang dimaksud adalah Paralegal yang melaksanakan pemberian bantuan hukum dan terdaftar pada Pemberi Bantuan Hukum. Oleh karena itu dapat dilakukan kegiatan sertifikasi terhadap Paralegal yang belum terdaftar pada $\mathrm{OBH}$ terakreditasi dengan diawali pendidikan dan pelatihan dengan menggunakan kurikulum yang ditentukan oleh Badan Pembinaan Hukum Nasional, yang akan dilaksanakan oleh $\mathrm{OBH}$, Universitas, atau lembaga 
lain yang bergerak di bidang hukum untuk kemudian didaftar pada organisasi bantuan hukum yang telah mendapatkan akreditasi oleh MENKUMHAM. (Arfan Faiz Muhlizi, 2019)

\section{KESIMPULAN}

Pengabdian Masyarakat Sudah sesuai target yang dijadwalkan oleh tim peneliti dengan melampau beberapa tahapan-tahapan penelitian yang telah dijadwalkan, dari tahapan persiapan dengan desa mitra dengan membuat langkah kerja dan persiapan, semua persiapan sampai pada akhir bulan Juli ini telah selesai dibuat dan siap dilaksanakan pengabidian kepada masyarakat di Desa Pagedangan Kecamatan Turen Kabupaten Malang dengan tema pengabdian "Pelatihan Dan Sertifikasi Bagi Paralegal Desa Pagedangan Kecamatan Turen Kabupaten Malang Demi Terciptanya Perlindungan Serta Pemenuhan Hukum Bagi Masyarakat".

Kebutuhan dari adanya masyarakat yang mengerti hukum ternyata sangat penting, dari hasil pelatihan banyak sekali masukan serta pertanyaan-pertanyaan serta pembahasan permasalahan yang ternyata selama ini masyarakat alami, sedangkan masyarakat tidak tau harus berbuat apa atau mengadi permasalahan mereka kepada siapa, dari adanya pelatihan paralegal ini masyarakat sangat antusias dan sangat merasa terbantu, paling tidak mereka bisa memiliki sedikit tambahan pengetahuan tentang hukum yang selama ini mereka alami.

\section{DAFTAR PUSTAKA}

Arfan Faiz Muhlizi. (2019). Penguatan Peran Tokoh Adat Sebagai Paralegal Dalam Memberikan Bantuan Hukum (Strengthening The Role of Indiginous People's Leader as Paralegal on Legal Aid Programm). Jurnal Rechts Vinding. Vol. 8, No. 1, April 2019.

Eka N.A.M Sihombing. (2019). Eksistensi Paralegal dalam Pemberian Bantuan Hukum bagi Masyarakat Miskin. Jurnal IImiah Penegakan Hukum. Vol. 6, No. 1, HIm 70-77.

Laurensius Arliman. (2017). Pendidikan Paralegal Kepada Masyarakat Sebagai Bentuk Perlindungan Anak Yang Berkelanjutan. UIR Law Review. Vol. 01, No. 01.

Sunggono, B \& Harianto, A. (2001). Bantuan Hukum dan Hak Asasi Manusia. Bandung. Mandar Maju.

Sigalingging, Abdul Azis, (et-al), (2015) Paralegal Berbasis Organisasi Rakyat, Aktor Kunci Gerakan Bantuan Hukum Berbasis Komunitas. Padang. LBH Padang.

Undang-Undang Republik Indonesia Nomor 16 Tahun 2011 Tentang Bantuan Hukum.

Undang-Undang Dasar Negara Republik Indonesia Tahun 1945.

Winarta, F.H. (2011). Bantuan Hukum di Indonesia (Hak untuk Didampingi Penasihat Hukum bagi Semua Warga Negara, Jakarta. Kompas Gramedia. 